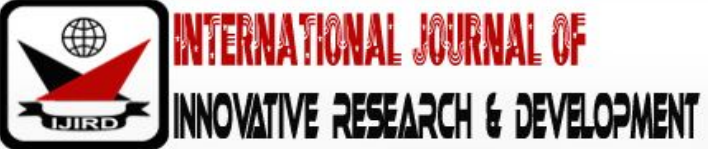

ISSN 2278 - 0211 (Online)

\section{The Sociological Impart of Corruption and Sharp Practices on the Public Image of the Nigerian Police Force in Ado Ekiti, Nigeria}

\author{
Ilori Oladapo Mayowa \\ Faculty of the Social Sciences, Department of Sociology, Ekiti State University, Ado Ekiti, Nigeria
}

\begin{abstract}
:
Corruption has become endemic in the Nigerian society today. Nearly all the facets of the nation are embroiled in one corruption case(s) or the other, even both the churches of God and men of God are not left out of the corruption scandal rocking the nation. In government offices, you have to rob the palm of the officials before you can get things done. Contracts are not awarded to the contractors who excel at the Tender interview except those that are ready to pay" kickbacks". Outside the country, anywhere a Nigerian is, there must be corruption. In other words, Nigeria represents corruption. One institution that has been grossly affected by the ocean of corruption sweeping across the nation is the Nigerian Police. Corruption in the Nigeria Police came to a climax when the former Inspectors General of Police were alleged and convicted of embezzling billions of naira from Police fund. The police checkpoints have been turned to cash points where members of the force on patrol make quick money. Corruption has continued to bedevil the rank and file of the Nigerian Police. The major objective of this study was to know how corruption has affected the image of the Nigerian Police. The study also looked at the perception of the Nigerians toward the Nigerian Police. Consequently, Ado Ekiti which is the state capital was used as the study area for the research. Because it is the capital city, it has a population of about one million and five hundred thousand inhabitants. Quantitative research method was adopted. In the light of this, questionnaires were used to source for information on the research objectives. The result of the research revealed that criminals often seek solace in Police to get freedom through bribery. At times Police often collude with the criminals to perpetrate crime. It was revealed that the Police have turned checkpoints to Automated Teller Machine (ATM) centres where they harvest the perception of the people towards the Police is that, the Police is lazy, corrupt, inefficient and trigger-happy. The result of the research revealed high level of corruption within the rank and file of the Nigerian Police. Also, there were recommendations on how to stem down the increasing rate of corruption in the Police. Also, there were recommendations on how to encourage then performances of the Nigerian Police.
\end{abstract}

Keywords: Corruption, checkpoint, police, perception, Automated Teller Machine (ATM)

\section{Introduction}

Corruption has become a cankerworm that impedes economic, social and political developments in Nigeria. The high rate of corrupt practises in almost all spheres of Nigeria society has placed the country at the top list of corrupt countries in ranking by the Transparent International (TI). It is highly disturbing that the Nigerian Police which is statutorily responsible for combating crime and corruption at all levels of our corporate existence has disappointedly become a brazen custodian of the sharp practises it was established to fight.

In a published Nigeria corruption index for 2007 by a Lagos based NGO, Independent Advocacy Project, rated the Nigeria Police as the most corrupt government institution, brought further despair rather than hope to the most Nigerians who have longed for a corrupt-free society.

In Nigeria, like many other nations, the Police have been the major organization charged with the responsibility of maintaining and preservation of public peace. Effective Police is therefore necessary in every society for maintaining peace, as effective Police will make sure that members of the community are safeguard in their persons and properties so that their energies are not exhausted by the business of self-protection (Onovo,2009).

The above implies that, maintaining peace does not only entail the protection of life and peace but also embraces the prevention and detection of crime. The apprehension of the offenders and the due enforcement of laws and regulations with which they are directly charged with. The assumption here is that, effective execution of the above-mentioned functions is tied to the smooth running of daily activities in every society, be it economic, social and political. However, the Nigerian Police as an entity is confronted by a lot of problems which invariably affect its efficient and effective functioning.

In the words of Basaru (2003) cited in Worobleski and Hess,2003, examples of Police corruption vary greatly in kind and degree, but they all have key element in common, the conduct is prohibited by law or rule. It involves misuse of position. Police corruption includes a wide variety of prohibited behaviours, either crime or departmental, rule violations committed under the auspices of a Police officer's position. At the same time, one cannot ignore the hues and cries that permeate the entire country over the perceived corruption of Nigerian Police. There has been widespread concern over the state of insecurity and seemingly inability of the Police to deal with the problems. 
This corruption is so entrenched that it is becoming virtually part of the system. Many people who have course to deal with the Nigerian Policeman and or Policewoman have revealed that the Police harbour some very bad characters (Pekuliameesi 2005). The matter is becoming more alarming hence the routine misuse of firearms by the Nigerian Police and their complete disdain for the people has become the norm.

Beginning from Tafa Balogun who was dismissed and convicted for stealing over \#11b in 2004 and his successor, Sunday Ehindero who was also in 2007 at the centre of a \#21m scan believed to be part of an undisclosed large sum that was caught while it was being smuggled out of the Police Headquarters in Abuja in the thick of the night, it goes without saying that not even the succeeding heads of the Police are excluded in the rot that has been made of the Nigerian Police. While Nigerians are still confounded over the \#21m theft, another \#354m fraud was again uncovered at the Police Headquarters. Other allegations against Sunday Ehindero included diversion of allowances of officers and men of the Police who took part in April 2007 elections as well as allowances of officers who went on peace keeping mission in Darfur and Monronvia.

There could not have sincerely been an efficient Police in the face of monumental embezzlement by officers at the top. The best such could give us is an ill-equipped Police full of officers and men who have been alienated from their statutory role of maintaining law and order in addition to protecting lives and property of Nigerians.

The greatest import of trouble with the Nigerian Police is that the Police in its present form and structure needs fundamental transformation and restructuring of the rank and file of the Police is strategic to changing this unbecoming trend and also to turn around the battered image and uncultured orientation within the Police.

\subsection{The Nigerian Police and Performance in the Face of Corruption}

Skolnick (1996) submitted "the Police in democratic society are required to maintain order and to do so under the rule of law. As functionaries charged with maintaining order, they are part of the bureaucracy, emphasizes the rights of the individual citizens and constraints upon initiatives of the legal officers. The tension between the operational consequences of order, efficiency and initiative on the one hand and legality on the other constitute the principal problem of the Police as a democratic legal organisation".

Skolnick (1996) in the above quotation was talking of the dichotomy between law and order that is between legal procedures and due process versus professional bureaucratic policy activity.

The Police view their job as one of technical proficiency of basic concepts of due process as fundamental to the work of both the Police and the Court. A basic problem with the Police throughout the world is how to establish and institute a clement among them and the public. In essence, a cordial police-public relation which is a sine qua nor for effective and efficient work performance on the Police because the Police cannot operate in isolation from the public. On the other hand, certain segments of the society including personnel of the Police organisation do not believe that the Police are inefficient in the performance of its constitutional responsibility.

According to the former Inspector General of Police and the current chairman of Police Service Commission (PSC), Mr Mike Okiro "the Police is underfunded and lack of excellent modern means of communication". For Osanyande "the problems confronting Police are legion and hence remained in surmountable over the years because of lack of sincerity of purpose on the part of successive government in Nigeria." Those at the helm of affairs under the protracted military rule saw Police likely "opposition force" and therefore wasted no time in rendering it impossible because the military felt the Police was its sub planters. The resultant and effect according to him is that, over the years the Police became grossly under-funded, ill-equipped and poorly motivated.

Another reason often cited by the Police is that the manpower component of the Police compared to the Nigerian population is far inadequate. Whereas the United Nations (UN) suggest a ratio of 1:400 but in Nigeria, the ratio is simply more than 1:500 for the Police, the manpower component has remained stagnant for a long time because recruitment into the Police was embargoed until recently under this democratic dispensation.

Corroborating the strained Police-public relation vis a vis corrupt practices, Tekena Tamuno (1993) observed that the strained Police public relation is traceable to the failure to keep the morale of the Police high, making its men and women to become negligent, corrupt, non-sensitive to the plight of Nigerians, thus destroying the image of the Police in the society. From the above, Tekena Tamuno was of the opinion that the inability of the successive government to boost the morale of the Police has increased tendencies of corrupt practices in the Nigerian Police. He further said that the increased corruption in the Nigeria Police has made the Police-public image to be dented.

Worried by the negative public attitude against the Nigerian Police, the former Inspector General of Police, Alhaji Ibrahim Coomassie, advised the officers and men of the Police to be upright and work towards redeeming the image of the institution. He spoke at a joint workshop organised by the National Orientation Agency (NOA) and the Police in Jos, Plateau State. He said "the Police owed it a duty to repudiate the bad image of the Police, improve the lot of our country and save the future of our children, the clear manifestation of indiscipline, corruption, general anarchy, nepotism and unbridled violations of legal laws in our society has made it abundantly necessary for us to mobilise our collective sense of justice, to fight all social ills militating against the realization of social justice."

Delivering a paper titled "Police and social justice "the Inspector General of Police averred that the twin evil of corruption and indiscipline have polluted all basic institutions of the Nigeria nation, affecting the formal groups of law and order and contaminating even the administration of justice.

According to Alhaji Ibrahim Coomasie, the increasing level of crime and corruption made the responsibilities of the Police more complex and it is therefore most unfortunate that the public associates this laudable institution with the problems of social injustice and irregularities. The Police have become a whipping horse for all and sundry, the public and the government alike. In Nigeria, the Police have been maligned, battered and dismembered, yet any time a citizen becomes a 
public figure, his official correspondence on assuming duty is to write IG to ask for an orderly and policemen to guard his house.

He said it is ironical that the Police are praised when the crime rate is low and condemned when the reverse is the case. It is the same Police that is condemned here in Nigeria that has been adjudged the best in Africa through the performance of its men who were sent on peace keeping operations to Namibia, Angola, Cambodia, Mozambique, Rwanda and Somalia.

Identifying actors that have continuously worsened the crime wave and corruption in Nigeria to include get rich syndrome, depressed economy, use of hard drugs, poor home up-bringing, ostentatious living, obstruction of justice, loss of confidence in law enforcement personnel, the negative attitude of mass media and the increasing involvement of outlaws in uniform in sophisticated crimes, Alhaji Ibrahim Coomasie said, "whether members of the military, immigration, prison, customs or other services, voluntary organisations, politicians, essential services departments and agencies, all hands must be on deck".

Grandiose Parlour (2005), writing on the Nigeria Police submitted that "to say that the Nigeria Police is an epitome of corruption and lawlessness is an understatement, the decadence that have pervaded the rank and file of the Police runs deep and wide, from the former Police bosses that stole millions of dollars, to the killing of innocent traders in Apo Business District in Apo, Abuja and for being the ubiquitous trigger-happy, bribe-demanding highway menace. Abundant instances exist that qualifies the Police as the Nigerian crock-pot of embarrassment, ineptitude and corruption, and it is fast turning into a national catastrophe of huge proportions. In addition to their blatant disregard for human right, it is also a common knowledge that when offered the right and adequate encouragement many Nigerian Police Officers can be bought and made to settle scores on one's behalf, either through simple threat and harassment or by making your adversary serve a short jail time lace with torture or through more heinous means that will rather not mentioned. Some Policemen have been known to aid and abet criminals."

From the above, Grandiose particularly believed that corruption is an endemic in the Police Institution in Nigeria. He noted that the rank and file are so corrupt that former Inspector Generals were arrested for stealing millions of dollars. He further said that Nigerian Police usually assist criminals to perpetrate their evil act. He believed that the Police check point have been turned into cash points where Police on duty exhort money from motorists.

An editorial review of Punch newspaper of Saturday,16 th July, 2005 observed that millions of dollars have been pumped into the Nigerian Police, yet the organisation remains comatose, grossly inefficient and crime rate is perennially high nationwide. The mere physical appearance of a Policeman indicates that the many billions invested in the Police are yet to trickle down to those of lower ranks. In fact, the majority of low ranking Policemen have defended their bribeseeking tendencies to "lack of adequate welfare for the rank and file of the Police". Using the statement from a Policeman on a highway duty, Punch (2005);

Why won't I collect \#20?. Sometimes, you assume that the Police are receiving so

Much money from the government. That is not true; we do not see the money.

In fact, we read it in the paper the way you people also read it. Now look at that

Patrol van. We buy fuel, we buy our own boots, uniforms and pay for our accommodation. Those are things that are supposed which we are to get through

Official funding. If you die on duty, your family suffers and if our colleague dies on

In the line of duty, we contribute money to take of the burial expenses......................

This paper further observed that "what the Police deserves and urgently needs is a genuine and fair reaching reform that transcends the usual window dressing that is characterised of Abuja. It is only a complete and thorough overhauling of the Police coupled with adequate funding that will redeem its image and bring dignity to the rank and file".

Benjamin Anosike (2007), in "the Nigerian Police; still the hot bed of public corruption in Nigeria" observed that almost always coming annually at the very top of the scale in the corruption index of the nation, the Nigerian Police has had a long-standing notorious history of corruption which is nothing short of legendary even in Nigeria. The nationwide survey of corruption in the Nigeria Corruption Index (NCI) of 2007, for example, released by Independent Advocacy Project (IAP), a non-governmental organisation with focus on good governance identified the Nigerian Police as the most corrupt organisation in the country, closely followed by erstwhile Power Holding Company of Nigeria. The Police is charged with being the most corrupt in terms of taking bribes and exhorting money from the populace. In other words, the Nigerian Police, the principal body which should be at the very fare front of combating crime and corruption in Nigeria, has always been, but remains today, even with all the much-publicised dreaded efforts of the Economic and Financial Crime Commission (EFCC), at the fore front, nor of combating the scourge of corruption and corruption-peddling in the nation.

\section{Theoretical Framework}

\subsection{Labelling Theory}

In this study, labelling theory will be adopted. The theory provides a distinctively sociological approach that focuses on the role of social labelling in the development of crime and deviance. The theory assumes that although deviant behaviour can initially stem from various causes and conditions, once individuals have been labelled or defined as deviant, they often face new problems that stem from the reactions of self and others to negative stereotypes (stigma) that are attached to the deviant label (Becker, 1963; Lemert,1967). These problems in turn can increase the likelihood of deviant and criminal behaviour becoming stable and chronic. 
In the words of Lemert (1967), deviant behaviour can become "means of defence", attack, or adaption" to the problems created by deviant labelling. Thus, being labelled or defined by others as a criminal offender may trigger processes that tend to reinforce or stabilise involvement in crime and deviance.

More socially representative's individuals such as Police Officers or Judges may be able to make more globally respected judgements. If deviance is a failure to conform to the rules observed by most of the group, the reaction of the groups to label the person as having offended against their social or moral norms off behaviour. This is the power of the group, to designate breaches of their rules as deviant and to treat the person differently depending on the seriousness of the breach. The more differential the treatment, the more individual's self-image is affected.

In Nigeria, the Police have been labelled as corrupt. The labelling of Police as corrupt by the public is sequel to the bad habit which is prevalent among the rank and file. Even in a situation in which Police perform excellently well, public still do not give kudos to them. For instance, if Police kills members of robbery gang, people do not see anything spectacular about it, because public have labelled the Police as an organisation that cannot achieve any success.

\subsection{Statement of Problem}

Corruption has become a major problem facing the Nigerian Police especially in the recent times. Two former Inspector Generals of Police were alleged of large scale fraud which even led to the conviction of one of them. On the roads, Police are even worse, those that are scheduled to be on patrol usually extort money from motorists. Any motorist that refuses to part with this stipend may be shot under the disguise of "accidental discharge". This was confirmed on $13^{\text {th }}$ December, 2017 when a driver was shot dead at Oye Ekiti in Ekiti State simply because he refused to part with a sum of \#50 demanded by the Police on check point.

Furthermore, there are some instances in which members of the Police will give their arms and ammunition to gang of robbers for robbery operations. Some are even in the habit of colluding with and / or assisting the robbers in their robbery operations so that they can get share from the robbers' loots. In some situation robbers do bribe the Police so that they (Police) can avoid coming to the area/ scene of robbery.

All the above have made the Police to be labelled as corrupt and subsequently loose its integrity. This loss of integrity by the Police has increased the rate of jungle justice in the country.

\section{Research Questions}

This research is intended to profound answers to some societal questions in respect of the Nigerian Police. In other words, the research is aimed to answer the following questions;

- Is Nigerian Police truly a corrupt institution or the Police is just being labelled as corrupt.

- What are the factors that are responsible for corrupt practices in the Nigerian Police?

- Can corrupt practises be controlled or curbed in the Nigerian Police.

- How to curb corrupt practises in Nigeria Police.

3.1. Objectives of the Study

The objectives of this study are as follows;

- To know how corruption has affected the public image of the Nigerian Police.

- To know how corruption has affected the Nigerian Police performance vis-à-vis crime control and the maintenance of law and order.

- To know how corruption can be curbed and/ or controlled within the rank and file of the Nigerian Police.

- To determine how police public image can be enhanced, so that public can trust Police again.

\subsection{Research Hypothesis}

Here, there is the use of hypothesis, which is assumed to serve as a tentative generalisation whose ability is to test in the basis of compatibility of its implication with empirical evidence. However, the following hypothesis shall be tested in this study;

- There is no significant relationship between corrupt practices in the Police and level of performance.

- There is no significant relationship between corrupt practices in the Police and the Police public image.

\subsection{Research Design}

This is a descriptive research. It describes how corruption has affected the image of the Nigerian Police in Ado Ekiti, Ekiti State, Nigeria. To this end, Ado Ekiti was chosen for this study being the capital city of the state and the most populous town in the state. Also, being a quantitative research, a total number of three hundred questionnaires were used with the respondents cutting across the state capital.

Multi-stage random sampling was used for the study. A stratified random technique was used. Statically Package for Social Science was used for the data analysis. Data collected from the field were analysed using both descriptive and inferential statistics.

\subsection{Problems Encountered}

Based on the method of data collection, some problems were encountered during the process of data collection. Some of these respondents returned their questionnaires late thereby creating problems for the researcher during the analysis. Some even said that since the researcher takes little or much of their time, they need to be compensated but after persuasion, they agreed to answer the questionnaires. 


\section{Data Analysis}

\begin{tabular}{|c|c|c|c|c|c|c|c|c|c|c|c|c|c|}
\hline & & $\begin{array}{c}\text { Stro } \\
\text { Ag }\end{array}$ & $\begin{array}{l}\text { ngly } \\
\text { eed }\end{array}$ & & & Dis & ree & & $\begin{array}{l}\text { igly } \\
\text { gree }\end{array}$ & & nse & & \\
\hline $\mathrm{S} / \mathrm{N}$ & Items & $\mathrm{Fq}$ & $\%$ & $\mathrm{Fq}$ & $\%$ & $\mathrm{Fq}$ & $\%$ & $\mathrm{Fq}$ & $\%$ & $\mathrm{Fq}$ & $\%$ & $\mathrm{Fq}$ & $\%$ \\
\hline a. & Bail is free & 18 & 6.0 & 28 & 9.3 & 186 & 62.0 & 66 & 22.0 & 2 & 0.7 & 300 & 100 \\
\hline b. & $\begin{array}{c}\text { Calling } \\
\text { policemen for } \\
\text { an arrest of } \\
\text { offenders has } \\
\text { been free of } \\
\text { charge }\end{array}$ & 57 & 19.0 & 25 & 8.3 & 182 & 60.7 & 34 & 11.3 & 2 & 0.7 & 300 & 100 \\
\hline C. & $\begin{array}{l}\text { Police collect } \\
\text { illegal money at } \\
\text { the check } \\
\text { points }\end{array}$ & 18 & 6.0 & 28 & 9.3 & 186 & 62.0 & 66 & 22.0 & 2 & 0.7 & 300 & 100 \\
\hline d. & $\begin{array}{l}\text { It does not } \\
\text { matter the } \\
\text { content of my } \\
\text { luggage, } \\
\text { offenders can } \\
\text { bribe their way } \\
\text { through } \\
\end{array}$ & 139 & 46.3 & 143 & 47.7 & 5 & 1.7 & 11 & 1.3 & 2 & 0.7 & 300 & 100 \\
\hline e. & $\begin{array}{c}\text { I believe } \\
\text { policemen do } \\
\text { collude with } \\
\text { robbers in } \\
\text { some cases }\end{array}$ & 93 & 14.3 & 33 & 11.0 & 195 & 65.0 & 27 & 9.0 & 2 & 0.7 & 300 & 100 \\
\hline f. & $\begin{array}{l}\text { Due process are } \\
\text { usually } \\
\text { followed } \\
\text { whenever I am } \\
\text { involved in } \\
\text { police cases }\end{array}$ & 132 & 44.0 & 156 & 52.0 & 7 & 2.3 & 3 & 1.0 & 2 & 0.7 & 300 & 100 \\
\hline g. & $\begin{array}{l}\text { Policemen do } \\
\text { collect bribe on } \\
\text { highways }\end{array}$ & 106 & 35.3 & 131 & 43.7 & 40 & 13.3 & 21 & 2.0 & 2 & 0.7 & 300 & 100 \\
\hline h. & $\begin{array}{c}\text { Policemen } \\
\text { often boycott } \\
\text { their duties to } \\
\text { do odd jobs }\end{array}$ & 83 & 27.7 & 81 & 27.0 & 116 & 38.7 & 18 & 6.0 & 2 & 0.7 & 300 & 100 \\
\hline i. & $\begin{array}{l}\text { Criminals seek } \\
\text { solace in police } \\
\text { to get their } \\
\text { freedom } \\
\text { through bribery }\end{array}$ & 122 & 40.7 & 167 & 55.7 & 6 & 2.0 & 3 & 1.0 & 2 & 0.7 & 300 & 100 \\
\hline $\bar{j}$. & $\begin{array}{l}\text { Police cannot } \\
\text { render help to } \\
\text { citizens without } \\
\text { collecting bribe }\end{array}$ & 128 & 42.7 & 161 & 53.7 & 6 & 2.0 & 3 & 1.0 & 2 & 0.7 & 300 & 100 \\
\hline
\end{tabular}

Table 1: Frequency and Percentage Distribution Showing Perception of People towards Police Corruption Practices

The above table revealed the perception of the public towards corruption in the Police. The table showed that 18 respondents (6\%) strongly agreed that bail is free at the Police stations. 28 respondents (9.3\%), agreed that bail is freed at the Police stations. It showed that 186 respondents, (62\%) disagreed that bail is free at the Police stations. 66 respondents (20\%) strongly disagreed that bail is free while 2 respondents $(0.7 \%)$ did not respond to this question.

Furthermore, 57 respondents (19\%) were of the opinion that calling Police for an arrest of offenders has been free of charge. 25 respondents (8.3\%) agreed to this opinion. 182 respondents $(60.7 \%)$ disagreed that calling Police for an arrest of offenders has been free of charge. 34 respondents (11.3\%) strongly disagree in this assertion. 2 respondents $(0.7 \%)$ did not respond to this question.

18 respondents (6.0\%) strongly agreed that Police collect illegal money at the checkpoints. 28 respondents (9.3\%) agreed that Police collect illegal money at the checkpoints. 186 respondents (62.0\%) disagreed strongly that Police collect illegal money at the checkpoints. 66 respondents $(22.0 \%)$ strongly disagreed that Police collect illegal money at the 
checkpoints. 2 respondents (0.7\%) failed to answer this question. 139 respondents (46.3\%) strongly agreed that it does not matter the content of your luggage, offenders can bribe their way through. 143 respondents $(47.7 \%)$ agreed that it does not matter the content of any luggage, offenders can bribe their way through. 5 respondents $(1.7 \%)$ disagreed that it does not matter the content of luggage, offenders can bribe their way through. 11 respondents $(3.7 \%)$ strongly disagreed that it does not matter the content of the free luggage, offenders can bribe their way through. 2 respondents (0.7\%) failed to answer the question.

It is revealed that 43 respondents (14.3\%) strongly agreed that Police do collude with robbers in some cases. 33 respondents (11.0\%) agreed that Police collude with robbers. 195 respondents (65.0\%) disagreed that Police collude with robbers while 27 respondents $(9.0 \%)$ strongly disagreed with this view. 2 respondents $(0.7 \%)$ did not respond to the question.

106 respondents (35.3\%) strongly agreed that Police collect bribe on the highways. 131 respondents (43.7\%) agreed that Police do collect bribe on the highways. 40 respondents (13.3\%) disagreed that Police collect bribe on the highways. 21 respondents (7.0\%) of the respondents strongly disagreed with this view.

The table further revealed that 83 respondents (27.7\%) strongly agreed that Police often boycott their duties to do odd jobs. 81 respondents $(27.0 \%)$ agreed with this view. 116 respondents (38.1\%) disagreed that Police often boycott their duties to do odd jobs while 18 respondents (6.0\%) strongly disagreed.

Also, 122 respondents (40.7\%) strongly agreed that criminals seek solace in Police through bribery for their freedom. 167 respondents (55.7\%) did agreed that criminals seek solace in Police to get their freedom through bribery. 6 respondents $(2.0 \%)$ disagreed with this view while 3 respondents (1.0\%) strongly disagreed.

128 respondents $(42.7 \%)$ strongly agreed that Police could not render help to public without collecting bribes. 161 respondents (53.7\%) agreed that Police could not render help to the public without collecting bribe. 3 respondents (1\%) expressed their strong disagreement on this view.

The table revealed that the Nigeria Police is corrupt and this has affected its image negatively. In the table, we can see that $55 \%$ of the respondents believed that it is an ideal thing to offer bribe to Police at the checkpoints/ police stations. It was shown in the table that 155 respondents (51.7\%) disagreed that they can take up career in the Police. In other words, the negative image of the Nigerian Police has made an average Nigerian not to be interested in going for a career in the Police. It is discovered that nowadays, parents and guardians do discourage their wards and children from joining Police. On the streets, public no longer regard Police as a profession, people now believed that anybody that joins Police is as a result of frustrations. The negative public image of the Police has made public to lose interest / confidence in its activities, for instance, during robbery incidences, people prefer to call members of local vigilante or in some cases results to jungle justice rather than inviting Police. Not this alone, at checkpoints, the Police preferred to extort money from innocent motorists rather than doing what they are ought to do.

Grandiose (2005), particularly believed that "corruption is endemic in the Police institution in Nigeria." He further submitted that the rank and file of the Police are so corrupt that the former Inspector Generals of Police were arrested for stealing millions of dollars. He said the Police usually assist criminals to perpetrate their evil act. He believed that the Police checkpoints have been turned into cash points where Police on duty exhort money from motorists.

\begin{tabular}{|c|c|c|c|c|c|c|c|c|c|c|c|c|c|}
\hline \multicolumn{2}{|c|}{} & $\begin{array}{c}\text { Strongly } \\
\text { Agreed }\end{array}$ & \multicolumn{2}{c|}{ Agreed } & \multicolumn{2}{c|}{ Disagree } & \multicolumn{2}{c|}{$\begin{array}{c}\text { Strongly } \\
\text { Disagree }\end{array}$} & \multicolumn{2}{c|}{$\begin{array}{c}\text { No } \\
\text { Response }\end{array}$} & \multicolumn{2}{c|}{ Total } \\
\hline S/ N & Items & $\mathrm{Fq}$ & $\%$ & $\mathrm{Fq}$ & $\%$ & $\mathrm{Fq}$ & $\%$ & $\mathrm{Fq}$ & $\%$ & $\mathrm{Fq}$ & $\%$ & $\mathrm{Fq}$ & $\%$ \\
\hline a. & $\begin{array}{c}\text { Crime rate in Ekiti is } \\
\text { reducing }\end{array}$ & 65 & 21.7 & 92 & 30.7 & 129 & 43.0 & 12 & 4.0 & - & - & 300 & 100 \\
\hline b. & $\begin{array}{c}\text { Incidence of rubbery is } \\
\text { not rampant in Ekiti }\end{array}$ & 144 & 48.0 & 144 & 48.0 & - & - & 12 & 4.0 & - & - & 300 & 100 \\
\hline C. & $\begin{array}{c}\text { Police on patrol are very } \\
\text { effective }\end{array}$ & 19 & 6.3 & 19 & 6.3 & 124 & 41.3 & 143 & 47.7 & - & - & 300 & 100 \\
\hline d. & $\begin{array}{c}\text { Bail is free in recent } \\
\text { times }\end{array}$ & 5 & 1.7 & 50 & 16.7 & 43 & 14.3 & 202 & 67.3 & - & - & 300 & 100 \\
\hline e. & $\begin{array}{c}\text { Accused are treated as } \\
\text { suspect rather than as } \\
\text { offenders }\end{array}$ & 5 & 1.7 & 51. & 17.0 & 153 & 51.0 & 86 & 28.7 & 5 & 1.7 & 300 & 100 \\
\hline f. & $\begin{array}{c}\text { Police do organise } \\
\text { orientation programmes } \\
\text { on service delivery }\end{array}$ & 178 & 59.3 & 68 & 22.7 & - & - & 54 & 18.0 & - & - & 300 & 100 \\
\hline g. & $\begin{array}{c}\text { Police at check point are } \\
\text { thorough at checking } \\
\text { necessary documents of } \\
\text { motorists }\end{array}$ & 13 & 4.3 & 9 & 3.0 & 50 & 16.7 & 228 & 76.0 & - & - & 300 & 100 \\
\hline h. & $\begin{array}{c}\text { Police are not biased in } \\
\text { their conducts }\end{array}$ & 1 & 0.3 & 18 & 6.0 & 20 & 6.7 & 261 & 87.0 & - & - & 300 & 100 \\
\hline
\end{tabular}

Table 2: Frequency and Percentage Distribution Showing Police Level of Performance

The above table showed that 65 respondents (21.7\%) strongly agreed that crime rate in Ekiti is reducing. 92 respondents (30.7\%) agreed that crime rate in Ekiti is reducing. 129 respondents (43.0\%) disagreed that crime rate in 
Ekiti is reducing. 12 respondents (4.0\%) strongly disagreed that crime Jrate in Ekiti is reducing. 144 respondents (48.0\%) both agreed and strongly agreed that incidence of robbery is not rampant in Ekiti while 12 respondents (4.0\%) expressed strong disagreement on this.

19 respondents (6.3\%) strongly agreed that police on patrol are very effective. 124 respondents (41.3\%) disagreed that Police on patrol are effective. 143 respondents (47.7\%) strongly disagreed that Police on patrol are very effective. The table further showed that 5 respondents (1.7\%) strongly agreed that bail is free in recent times. 50 respondents (16.7\%) agreed that bail is free. 43 respondents (14.3\%) strongly disagreed that bail is free. 202 respondents $(67.3 \%)$ strongly disagreed that bail is free.

5 respondents $(1.7 \%)$ strongly agreed that accused are treated as suspects rather than as offenders. 51 respondents (17.0\%) agreed that accused are treated as suspects rather than as offenders. 153 respondents (51.0\%) disagreed that accused are treated as suspects rather than as offenders. 86 respondents (28.7\%) strongly disagreed that accused are treated as suspects rather than as offenders. 5 respondents did not respond to the question.

178 respondents $(59.3 \%)$ strongly agreed that Police do organise orientation programme on service delivery. 68 respondents (22.7\%) agreed that Police do organise orientation programme on service delivery. 54 respondents (18.0\%) strongly disagreed on this view.

13 respondents (4.3\%) strongly agreed that Police at the checkpoints are thorough in checking the documents of motorists. 9 respondents (16.7\%) disagreed that Police at the checkpoints are thorough in checking necessary documents of the motorists. 228 respondents (76.0\%) strongly disagreed on this view.

In another development, 1 respondent $(0.3 \%)$ strongly agreed that Police are not biased in their conducts. 261 respondents (87.0\%) strongly disagreed that Police are not biased in their conducts. 18 respondents (6.0\%) agreed that Police are not biased in their conducts. 20 respondents (6.7\%) disagreed that police are not biased in their conducts.

From the above table, 167 respondents (55.7\%) agreed that criminals do seek solace in Police for their freedom by bribing their way through. In the light of this, people believed that Police do assist criminals in carrying out their evil acts. This is evident in the jungle justice which public embark on at times because they know that any accused criminal in Police custody can bribe his/ her way out to freedom.

The table also indicated that 429 respondents (43\%) disagreed that crime rate in Ekiti is reducing while 143 respondents (47.7\%) strongly disagreed that Police on patrol are very effective. From these findings, it can be deduced that Police are not very effective on their patrol and this has made the level of crime to rise in the state. Even people believed that Police on patrol often collect bribes and this affects their image in the long run.

\begin{tabular}{|c|c|c|c|c|c|c|c|c|c|c|c|}
\hline \multicolumn{2}{|c|}{} & \multicolumn{2}{c|}{ Not at All } & \multicolumn{2}{|c|}{ Little } & \multicolumn{2}{|c|}{ Moderately } & \multicolumn{2}{|c|}{ No Response } & \multicolumn{3}{|c|}{ Total } \\
\hline S/ N & Items & $\mathrm{Fq}$ & $\%$ & $\mathrm{Fq}$ & $\%$ & $\mathrm{Fq}$ & $\%$ & $\mathrm{Fq}$ & $\%$ & $\mathrm{Fq}$ & $\%$ \\
\hline a. & $\begin{array}{c}\text { Prompt payment of } \\
\text { salaries }\end{array}$ & 68 & 22.7 & 200 & 66.7 & 30 & 10.0 & 2 & 0.7 & 300 & 100 \\
\hline b. & $\begin{array}{c}\text { Regular upward review of } \\
\text { salaries and all allowances }\end{array}$ & 64 & 21.3 & 199 & 66.3 & 35 & 11.7 & 2 & 0.7 & 300 & 100 \\
\hline c. & Salaries advancement & 229 & 76.30 & 69 & 23.0 & - & - & 2 & 0.7 & 300 & 100 \\
\hline d. & $\begin{array}{c}\text { Loans given out to police } \\
\text { officers and men }\end{array}$ & 258 & 86.0 & 40 & 13.3 & - & - & 2 & 0.7 & 300 & 100 \\
\hline e. & $\begin{array}{c}\text { Pension schemes and } \\
\text { gratuity }\end{array}$ & 10 & 3.3 & 249 & 83.0 & 39 & 13.0 & 2 & 0.7 & 300 & 100 \\
\hline f. & $\begin{array}{c}\text { Regular payment of fringe } \\
\text { benefits }\end{array}$ & 234 & 78.0 & 64 & 21.3 & - & - & 2 & 0.7 & 300 & 100 \\
\hline g. & Long service award & 273 & 91.0 & 25 & 8.3 & - & - & 2 & 0.7 & 300 & 100 \\
\hline h. & $\begin{array}{c}\text { Giving merit award to best } \\
\text { policeman/ policewoman } \\
\text { of the year }\end{array}$ & 135 & 45.0 & 139 & 46.3 & 24 & 8.0 & 2 & 0.7 & 300 & 100 \\
\hline i. & $\begin{array}{c}\text { Institution of scholarship } \\
\text { for police and their } \\
\text { children }\end{array}$ & 293 & 92.7 & 5 & 1.7 & - & - & 2 & 0.7 & 300 & 100 \\
\hline j. & $\begin{array}{c}\text { Promotion given when } \\
\text { due }\end{array}$ & 40 & 13.3 & 224 & 74.7 & 34 & 11.3 & 2 & 0.7 & 300 & 100 \\
\hline k. & $\begin{array}{c}\text { Timely payment of } \\
\text { seminar bonuses }\end{array}$ & 228 & 76.0 & 65 & 21.7 & 5 & 1.7 & 2 & 0.7 & 300 & 100 \\
\hline
\end{tabular}

Table 3: Frequency and Percentage Distribution Showing the Degree of Police Officers' Morale

From the above table, it can be deduced that 68 respondents (22.7\%) said that prompt payment of salaries and allowances will "not at all" improve the morale of Police. 200 respondents (66.7\%) believed that prompt payment of salaries and allowances will have "little" effect on the morale of Police. While 30 respondents $(10.0 \%)$ believed it only improved the morale of Police moderately. What this implies is that payment of salaries and allowances will have little effect on the morale of Police.

64 respondents $(21.3 \%)$ submitted that regular review of salaries and allowances will "not at all" increase the morale of Police. 199 respondents (66.3\%) believed that regular upward review of salaries and allowances would have 
"little" on the morale of Police. 35 respondents (11.7\%) believed regular upward of salaries and allowances will only have" moderate" effect on the morale of Police. The implication is that regular upward review of salaries and all allowances will only have "little" effect on the morale of the Police.

229 respondents (76.3\%) were of the opinion that salary advancement will increase the degree of Police morale. 69 respondents (23.0\%) believed that salary advancement will only have little effect on the morale of Police. What this is that giving of salary advancement will not at all have effect on the morale of Police.

258 respondents (86.0\%) believed that giving loans to Police will "not at all" increase the degree of morale of Police. 40 respondents (13.3\%) believed that giving loans out to Police will only have "little" effect on the morale of Police. 2 respondents $(0.7 \%)$ did not answer the question. The implication of this is that loans to Police will not at all increase the degree of morale of the Police.

The table further revealed that 10 respondents (3.3\%) believed that pension scheme and gratuity will "not at all" increase the degree of morale of Police. 249 respondents (83.0\%) submitted that pension and gratuity will only have "little" effect on the morale of Police. 39 respondents (13.0\%) believed that pension and gratuity will just moderately increased the degree of morale of Police. What this implies is that pension scheme and gratuity will have little effect on the degree of morale of Police.

234 respondents $(78.0 \%)$ opined that regular payment of fringe benefits will "not at all" increase the degree of morale of Police. 64 respondents (21.3\%) believed that regular payment of fringe benefits will have "little" effect on the morale of the Police. 2 respondents did not answer the question. The implication of this is that regular payment of fringe benefits will not at all increase the morale of Police.

273 respondents (91.0\%) believed that long service award will "not at all" increase the degree of morale of Police. 25 respondents (8.3\%) expressed their opinion that long service award will have "little" effect on the morale of Police. What this implies is that long service award will not at all increase the degree of morale of Police.

135 respondents (45.0\%) supported that giving merit award to the best Police of the year will not "not at all" increase the morale of Police. 139 respondents (46.3\%) believed that giving award to the best a Police will have "little" effect on the morale of Police. 24 respondents (8.0\%) believed giving merit award to the best Police of the year will have moderate increase in the morale of the Police. 2 respondents $(0.7 \%)$ failed to answer the question.

In another development, 293 respondents $(92.7 \%)$ believed that instituting a scholarship for Police and their children will "not at all" increase the morale of Police. 5 respondents (1.7\%) believed scholarship for Police and their children will only have a "little" effect on the morale of Police. It can be deduced that instituting scholarship for Police and their children will not at all increase the morale of the Police.

40 respondents (13.3\%) believed that promotion given when due will "not at all" increase the morale of Police. 224 respondents $(74 \%)$ believed promotion given when due will have "little" effect on the morale of Police. What this means is that promotion given when due will have little effect on the morale of Police.

208 respondents $(76.0 \%)$ submitted that timely payment of seminar bonus will "not at all" increase the morale of Police. 65 respondents $(21.7 \%)$ believed timely payment of seminar bonuses will have "little" effect on the morale of Police. 5 respondents $(1.7 \%)$ believed it will just moderately increase the morale of Police. From the table, it can be deduced that timely payment of seminar bonuses will not at all increase the morale of Police.

From the table above, it can be revealed that corruption in the Police can be reduced through:

- Prompt payment of salaries and other allowances.

- Regular upward review of salaries and other allowances.

- Pension scheme and gratuity.

- Giving merit award to the best Police of the year.

- Promotion given as and when due.

It is believed that when the above measures are taken into consideration, it can reduce and/ or curb corrupt practices in the Police and if this is achieved, the public confidence in the Police will be restored.

\begin{tabular}{|c|c|c|c|c|c|c|}
\hline Variable & N & Mean & SD & r & df & P \\
\hline Performance & 300 & 11.63 & 3.46 & -.14 & 298 & $<05$ \\
\hline Corruption & 300 & 16.41 & 1.53 & - & - & - \\
\hline
\end{tabular}

Table 4: Summary of Pearson Correlation Showing the Relationship between

Perceived Corrupt Practices and Level of Performance in Police

The table above shows that there is a significant relationship between perceived corrupt practices and level of performances in the Police in Ekiti State $[\mathrm{r}(298)=.14 ; \mathrm{p}<05]$. The relationship was a negative relationship. This implies that the higher the level of perceived corruption in the Police, the lower their level of performance. Thus, the null hypothesis which states that there is no significant relationship between perceived corrupt practises and level of performance is rejected.

\begin{tabular}{|c|c|c|c|c|c|c|}
\hline Variable & N & Mean & SD & r & df & P \\
\hline Public Image & 300 & 13.46 & 4.66 & -.13 & 298 & $<05$ \\
\hline Corruption & 300 & 16.41 & 1.53 & - & - & - \\
\hline
\end{tabular}

Table 5: Summary of Pearson Correlation Showing the Relationship between

Perceived Corrupt Practices and Public Image of Police 
The above table showed that there is a significant relationship between perceived corrupt practices and public image in the Police $[\mathrm{r}(298)=.13 ; \mathrm{p}<05]$. This negative relationship implies that the higher the level of perceived corrupt practises in the Police, the lower the public image. Thus, the null hypothesis which states that there is no significant relationship between perception of corrupt practises and public image in the Police is rejected.

\section{Conclusion}

Corruption has become a cankerworm that endangers the public image of the Nigerian Police. This practise has made an average Nigerian to lose confidence in the Police. Though it is always written boldly in the Police stations that "Police is your friend" "bail is free" etc, but public no longer believe in these assertions. The Police have been accused of many social vices like extra-judicial killings, colluding with robbers to perpetrate evil. The Nigerian Police do not enjoy the confidence, respect and support of the people again. The image many Nigerians have of the Police is that of "lazy", "corrupt", "inefficient", "bribe-taking" who connives at crime.

This study has revealed that there is a significant relationship between the public image of the Police and level of corruption in the Police. In other words, corruption has negatively affected the image of the Police. It was observed that the higher the level of corruption in the Police, the more dents its public image.

It was also showed that there is a relationship between corruption in the Police and the level of performance. In essence, the result justified that the more the force is corrupt, the lesser the level of performance.

\section{Recommendations}

Corruption within the Police is an indication of lack of professionalism within the Police. A professional organisation sets its own standards and strives to maintain such standards through self-regulation. To be admitted as a member of the profession, the applicant must possess the relevant skills, be competent have integrity and recognise the organisation's responsibility to provide excellent service to the community. Members of a professional organisation are proud of their membership and aspire to meet the standard of the organisation. Those who fail to meet the standards of the organisation and or are involved in conducts that degrade the profession have their membership terminated.

The most effective way to combat corruption in the Police is to foster a culture of professionalism within the rank and file of the Police. Professionalism organisations with the power to regulate itself can cultivate a culture of honesty, integrity and accountability. Their activities can also be shrouded in secrecy and may be overprotective of organisational image and such likely to cover up the misdeeds of a member rather than holding the member accountable.

Furthermore, human capital and operational capacity are another area in which the Police needs to be looked into. No organisation is able to carry out its functions without adequate and human resources with operational capacity. The Nigerian Police is refuted for harbouring only those who do not have anything to do. The Police should attract the best and brightest persons with certain minimum education and training. In United States of America, to join any Police department, the preferred candidates are persons with college education but since it is hard, the minimum is at least two years of college credit. When the Police attract men and women who have sense of dignity and respect for their fellow individuals which is what higher education is expected to help one achieve, some of the credibility and confidence question lacking in the Police will be addressed.

Also, the Internal Control System of the Police must be looked into. Internal Control System can be defined in general terms as core values, processes and mechanisms through which Police authorities regulate and guide the daily activities of their institutions and confront individual's acts of wrong doing. It also offers an important line of defence against corruption and abuse in the Police and provide a key measure in which Police authorities can hold its personnel accountable for abuse and other misconduct or inappropriate behaviour and by so doing promote positive relations with the community. Effective Internal Control System can assist in analysing and changing the regulatory and management systems and practises of the Police to refine their capacity and improve their performance both in their effectiveness and ethics.

Government should also look into the area of poor remuneration in order to reduce and / or curb corrupt practises in the Police. The Nigerian Police is poorly paid and this is affecting their performance. Government should improve on the remuneration of the Police and ensures money gets to the least officer in the Police.

Finally, the authority of the Nigerian Police should re-organise the Police checkpoints in accordance with its primary purpose.

\section{References}

i. Alemika. E.E (1988), "Policing and Perception of Police in Nigeria” Police Studies II, pp 161-179.

ii. Alemika. E.E (1999), "Policing in Contemporary Nigeria; Problems and Prospects" Paper presented at the Police Staff College, 23rd July,1999.

iii. Alemika. E.E (1995), "Criminology and Philosophy of Policing” in T.N Tamuno, et al (eds),Policing Nigeria, Past, Present and Future. Lagos Maltahouse Press Ltd. pp.30-78.

iv. Alemika.E.E (1993), "Crime Control and Criminal Justice; Theoretical Reflection " Paper presented at the National Conference on crime and crime control in Nigeria.

v. Bashir.I.L (1993), "Towards an Effective Nigeria ;Police on Policing Nigeria, Past, Present and Future (1993) " . Multahouse Press Ltd pp 585.

vi. Basaru,0,0 (2003), "Crime in the society; Currents and Perspective" in Uche-Abanihe,A.N Isamah and Adesina(eds), Current and Respective in Sociology, Lagos, Nigeria; Maltahouse Press Ltd.

vii. Benjamin.A. (2007), "The Nigerian Police; Still the Hot Bed of Public Corruption in Nigeria” London Macmillan. 
viii. Bituer. E. (1970), "The Functions of Police in Modern Society" Rockville, MD National Institute of Mental Health.

ix. Black D.B (1980), "The Manners and Customs of Police" New York Academic Press.

x. Box.S. (1989), "Power, Crime and Mystification" London Macmillan

xi. Bulter. T.O (1984) "Police Management" Gower publications.

xii. Bunyard. R.S (1978), "Policing Organisation and Command ". London English Language Book Society and Evans Ltd.

xiii. Commasie. I.(1996), " A Concise Approach to the Nigerian Police”. Lecture Delivered to Course 5 of the National War College pp3.

xiv. Coffey. A.R (1975), “The Prevention of Crime and Delinquency” Printice Hall.

xv. Constitution of the Federal Republic of Nigeria.

xvi. Dada. O. Adebayo (2010), "Gender and Attitudes Towards Professional Ethics; A Nigerian Police Perspective". Published in African Security Review vol.14 no.2.

xvii. Daily Trust Newspaper (2007). Pp50.

xviii. Dambazau. A.B (1994), "Law and Criminality in Nigeria”. Ibadan University Press.

xix. Ehindero. S.G (1986), "Police and the Law in Nigeria” Lagos Multahouse Press Ltd.

xx. Ehindero. S.G (1991), "The Constitutional Development of Nigeria 1949-1989”. Ehindero Nig.Ltd.

xxi. Ehindero. S.G (1995), "The Organisation and Command Structure of the Nigerian Police Force” Multahouse Press Ltd.

xxii. Ejike Okpa (2005), "Nigerian Police;An Empty of the People". Workshop on Human Capital and Operational Capacity in Nigerian Police Force.

xxiii. Garland. D. (1997), "Of Crimes and Criminals; the Development of Criminology in Britain".In Murgan et al (eds). The Oxford Handbook of Criminology ( $2^{\text {nd }}$ edition). Oxford University Press pp11-45

xxiv. Gerber.J (1972), "The Police Role in Determining Crimes". Beverly Hills London.

xxv. George Ritzer (1996), "Sociology Theory". University of Mary Press.

xxvi. Godpower .O. Okereke (1993), " Public Attitudes Toward the Police Force in Nigeria "Fayetteville State University, North Carolina, USA.

xxvii. Innocent Chukwuma (2005), "Improving Police-Community Relations in Nigeria. Workshop on Prevention of Violation of Human Rights in Nigeria pp 1-3.

xxviii. Jon Gunnar Brernburg (2009)," Handbook on Crime and Deviance"; pp 187-207.

xxix. Nigerian Tribune Newsletter of the Social Science Academy of Nigeria.

xxx. Okonkwo. C.O. (1966), "The Police and the Public in Nigeria”. African University Press Ltd Lagos.

xxxi. Tamuno. T.N (1970), "The Police in Modern Nigeria; Past, Present and Future”. Multahouse Press Ltd.

xxxii. The Punch Newspaper (2005). 